Annals of Warsaw University of Life Sciences - SGGW

Land Reclamation No 39, 2008: 21-31

(Ann. Warsaw Univ. of Life Sci. - SGGW, Land Reclam. 39, 2008)

\title{
Flood risk and vulnerability in the changing climate
}

\author{
ZBIGNIEW W. KUNDZEWICZ
}

Research Centre for Agricultural and Forest Environment, Polish Academy of Sciences, Poznan, Poland and Potsdam Institute for Climate Impact Research, Potsdam, Germany

\begin{abstract}
Flood risk and vulnerability in the changing climate. Floods are a natural phenomenon, striking the humankind since the dawn of history. Yet, recent flood damages are dramatically higher than before, so that it is necessary to seek interpretation of this fact. River flooding is a complex phenomenon which can be affected by changes coupled to physical, terrestrial, climate and socio-economic systems. The climate track in the observed changes is likely, even if human encroaching into the harm's way and increase in the damage potential in floodplains can be the dominating factors in many river basins. Increase in heavy precipitation has been observed, with consequences to increasing risk of rain-induced flooding. Projections for the future, based on regional climate models, indicate increase of flood risk and vulnerability in many areas. Impacts on urban flooding, in a multi-factor context are examined. The present contribution is following the global IPCC perspective, in the context of the IPCC Fourth Assessment Report and the IPCC Technical Paper on Water, where ZWK was a Coordinating Lead Author.
\end{abstract}

Key words: flood risk; vulnerability; climate change; heavy precipitation; flood protection; flood preparedness.

\section{INTRODUCTION}

Flooding, i. e. the destructive abundance of water, is a natural phenomenon, being of major concern of people populating the vicinity of rivers and water bodies since the dawn of history. Despite the fascinating recent developments in many areas of science and technology, the hazard of flooding has not been eradicated. In fact, floods seem to become more abundant and destructive in many regions of the world. Media inform us more and more frequently about disastrous floods. Some people believe that it can be a CNN-effect; in the past, before the globalization era, the timely information on far-away floods was not available. Now, the Dartmouth Floods Observatory (http://www.dartmouth.edu/ floods/) offers very valuable up-dated information on the floods worldwide. No matter where in the global village a destructive flood occurs, it is regarded as a spectacular event, and pictures from recently inundated areas are promptly included in the TV news worldwide.

Notwithstanding the increased availability of information, it is clear that the flood risk (understood as the probability of flood multiplied by a measure of its adverse consequences) is indeed on the rise, worldwide. The costs of extreme weather events have exhibited a rapid upward trend in recent decades and yearly economic losses from large events have increased ten-fold between 1950s and 
1990s, in inflation-adjusted dollars (IPCC, 2001) and flood damage has changed in a similar way. There have been several recent flood events, in each of which the material losses exceeded USD 10 billion. The death toll has remained high, with single events in less developed countries causing more than 1000 fatalities.

Destructive floods have been commonplace outside Europe, in particular in Asia (especially Bangladesh, China and India) and South America. In Bangladesh, during the 1998 flood, about $70 \%$ of the country area was inundated. However, over the last two decades, numerous floods have severely hit also large parts of Africa, Australia, North America, and Europe. For instance, the material flood damage recorded in Europe in 2002 (21 billion euros) was higher than in any single year before.

Flood risk and vulnerability have been growing over many decades and are projected to grow in the future. The present contribution aims to analyze the interpretation of this growth.

\section{MATERIALS AND METHODS}

As phrased in Webster's New Collegiate Dictionary, the adjective "vulnerable" means "capable of being physically wounded", or "open to attack or damage". According to IPCC (2007a), vulnerability to climate change is the degree to which geophysical, biological and socioeconomic systems are susceptible to, and unable to cope with, adverse impacts of climate change. Vulnerability depends on exposure to climatic stimuli (character, magnitude, and rate of climate change); sensitivity, and adaptive capacity of the system. The latter term means ability of the system to adapt (to curb potential damages, to cope with consequences, and to take advantage of opportunities). The adaptive capacity is a function of wealth, organization, legislation, education, awareness. Hence, vulnerability to floods depends on exposure (e.g. heavy precipitation) and adaptive capacity. Exposure, and adaptive capacity have been increasing in many areas, but the former often grows faster, so that vulnerability increases as well.

Although wealthy societies are willing to pay a high price to avoid low-probability disasters, floods strike also developed countries. Yet, fatality toll in developed countries is far less than in the developing ones. The ratio of material losses (in common reference currency) to a number of deaths (in simple words - material losses per one death) generally depends on the wealth, e.g. measured by GNP per capita. For catastrophic floods in developing countries, material losses per one fatality can be by four orders of magnitude lower than in developed countries (Kundzewicz and Takeuchi 1999). The poor are extremely vulnerable.

Risks from extreme climate events, such as floods, are among the principal reasons for concern and "key" vulnerabilities, identified via a set of criteria, such as magnitude, timing, persistence, reversibility, potential for adaptation, distributional aspects, likelihood, confidence in assessment, and 'importance' of the impacts (IPCC, 2007a).

In order to understand the changes in flood risk and vulnerability, it is necessary to review the mechanisms and the physics of the processes related to floods and flood damage, and then to analyze 
existing observation data and model projections for the future.

Flooding is a complex phenomenon, embracing such events as river floods, flash floods, urban floods and sewer floods, that can be caused by several mechanisms, such as intense and/or long-lasting rainfall, snowmelt, dike or dam break, reduced conveyance due to ice jams or landslides, or glacial lake outburst. Floods depend on precipitation, antecedent conditions of rivers and their drainage basins (e.g., presence of snow and ice, soil character, wetness - soil moisture saturation, urbanization, and existence of dikes, dams, or reservoirs), cf. Kundzewicz et al. (2007). Estuarine flooding and coastal flooding can be caused by strom surges - strong shoreward winds. One can identify three groups of factors which control flood hazard and vulnerability: changes in climate, changes in terrestrial systems (hydrological systems and ecosystems), and changes in socio-economic systems, whose relative order of importance is site-specific.

Changes in climate and atmospheric systems of relevance to floods embrace: precipitation (intensity, volume, timing, phase - rain or snow), air temperature (controlling snowmelt and ice-jam), seasonality and climate variability, e.g. El Niño - Southern Oscillation (ENSO); North Atlantic Oscillation (NAO). Changes in the frequency of heavy rainfall events can arise from several causes, e.g., changes in atmospheric moisture or circulation. As the atmosphere's water holding capacity, and thus its absolute potential water content, increase with air temperature according to the Clausius-Clapeyron law, the potential for heavy rainfall also increases in the warming world. Increased atmospheric moisture contents favours heavy precipitation events and this is a sufficient condition, caeteris paribus, for an increase in the risk of rain-caused floods. However, decreases in snow cover and river-ice cover in many areas of the temperate zone (such as Poland) lead to decrease in the risk of floods caused by snowmelt and ice jams.

Yet, there are also non-climatic factors exacerbating flood hazard. Land-use changes, which drive land-cover changes, induce changes of hydrological systems and control the rainfall-runoff relations, hence impacting on flood risk. Deforestation, reduction of wetlands, and rising urbanization have adversely influenced flood hazard in many watersheds by reduction of the available water storage capacity (in urban areas, streams are replaced by piping), increase in the portion of impervious area (roofs, yards, roads, pavements, parking lots, etc.) and in the runoff coefficient. This leads to growth in the amplitude and reduction in the time-to-peak of a flood. On average, $2 \%$ of agricultural land has been lost to urbanization per decade in the EU. Direct urbanization effects are particularly visible in small or middle size floods, which often constitute a substantial contribution to flood losses in the longer term. Van der Ploog et al. (2002) attributed the increase in flood hazard in Germany to climate (wetter winters), engineering modifications, but also to intensification of agriculture, large-scale farm consolidation, subsoil compaction, and urbanization. The urbanized area in West Germany more than doubled in the second half of 20th century. The timing 
of river conveyance can be altered by river regulation (channel straightening and shortening, construction of embankments).

In many regions, people have been encroaching into the harm's way, developing flood-prone areas, thereby increasing the damage potential. In Japan half of the total population and about $70 \%$ of the total assets are located on flood plains, which cover only about $10 \%$ of the land surface. There are mushrooming illegal settlements in endangered zones (e.g. flood plains) in developing countries.

An important factor influencing the flood hazard is an unjustified belief in the absolute security of structural defenses. However, a dike designed to withstand a 100-year flood, even if perfectly maintained, does not guarantee complete protection. It can be overtopped by an extreme flood (e.g. with return period of 1000 years). When a dike breaks, the damage may be greater than it would have been in a levee-free case. Under-dimensioning and poor maintenance of flood protection system do also contribute to rising risk.

In IPCC (2001), one finds statements that "the most widespread serious potential impact of climate change on human settlements is believed to be flooding" (IPCC, 2001, p. 395). A variety of settlements in different regions may be affected, although specific evidence is still very limited. Further, "riverine and coastal settlements are believed to be particularly at risk, but urban flooding could be a problem anywhere. ... Urbanization itself explains much of the increase in runoff relative to precipitation in settled areas ... and contributes to flood-prone situations" (IPCC, 2001, p. 395).
It is worthwhile to re-state a tautology: extreme events are rare (Kundzewicz and Schellnhuber 2004). They do not happen frequently, so there is a considerable uncertainty in estimating the average return period (recurrence interval) for extreme floods, even under present climate conditions. Even where a very long time series of instrumental records exists, one still deals with a small sample of truly extreme and destructive floods (cf. Kundzewicz and Robson 2004). These problems are amplified when making projections and drawing corollaries on low-probability flood events under future climatic conditions. This dilemma may only be resolved by deriving the correct probability density functions for disastrous events from first geophysical principles (Kundzewicz and Schellnhuber 2004).

Apart from the inherent complexity involved in detecting a greenhouse signal in river flow records, there are serious problems related to the data and to the methodology of change detection. Flood-related characteristics are influenced by multiple factors. Baseline conditions are rare, and human influence is typically strong (river regulation, deforestation, urbanization, dams and reservoirs). In order to detect a weak, if any, climate change component in the process of river flow, it is necessary to eliminate other influences and use data from pristine (baseline) river basins. Because of strong climate variability, records of less than 30 years are almost certainly too short for detection of climate change. It is suggested that at least 50 years of records are necessary for climate change detection (Kundzewicz and Robson 2004), but in the case of strong natural variability even this may not be sufficient. 
Impacts and adaptations are studied locally, hence locally-relevant projections are most interesting to people living there. This scale is very much different from the large scale of climate models, and even regional models, hence disaggregation is necessary. This scale mismatch between coarse resolution climate models and the hydrological (river-basin) scale is a source of uncertainty, particularly for flood extremes. Credibility in projections for the future is undermined by the fact that models cannot adequately cope with re-producing past climate extremes, in some regions, using global observations. Only in some areas the projected direction of change of precipitation or runoff is consistent across different scenarios (emissions of greenhouse gases, which drive climate models) and across different models.

\section{RESULTS AND DISCUSSION}

The frequency of heavy rainfall events (or proportion of total rainfall from heavy falls) has likely increased over most land areas, consistent with warming and observed increases in atmospheric water vapour (IPCC, 2007), with consequences to increasing risk of flooding. Some recent rainfall events in Europe have exceeded all-time records.

According to climate model results (HadRM3-P, Hadley Centre, United Kingdom), the mean summer precipitation over much of Europe is likely to decrease in the future, but the behaviour of precipitation extremes is notably different. Figure 1 illustrates the projected changes in percentiles of daily precipitation for the grid cell of the regional climate model HadRM3, containing the town of Poznań.

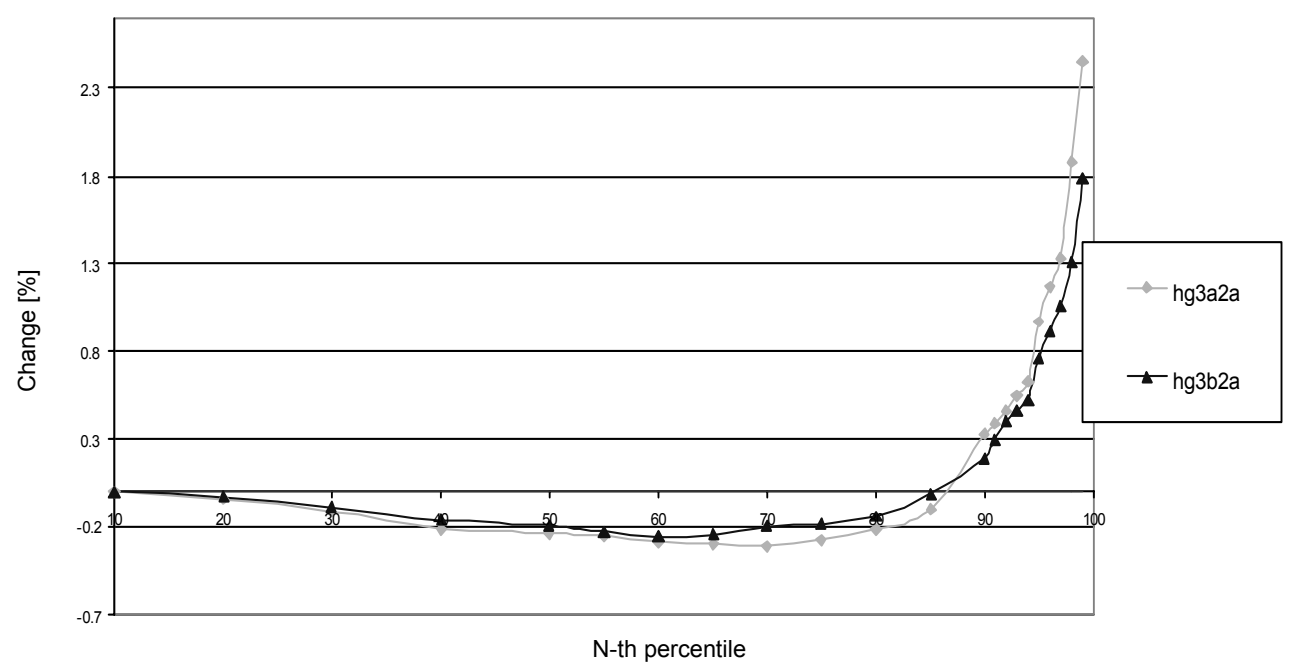

FIGURE 1. Projected changes in percentiles of precipitation for the grid cell of the regional climate model HadRM3, containing the town of Poznan. Changes refer to difference in N-th percentile of precipitation between the time horizon of future projection, 2070-2099 and the control period, 1961-1990. Two curves represent two model runs 
Changes refer to difference in the $\mathrm{N}$-th percentiles of precipitation between the time horizon of future projection, 2070 -2099 and the control period, 1961-1990. The lower percentiles are projected to decrease in the future, while the higher percentiles are projected to increase. The higher percentiles of daily precipitation, corresponding to heavy rainfall, are responsible for many floods.

The highest quartiles of daily precipitation amounts and annual maximum daily precipitation are anticipated to increase over many areas, also where the mean precipitation is projected to decrease (Kundzewicz et al. 2006). Increase in precipitation extremes has direct consequences to river floods, flash floods, groundwater floods, and land slides.

Palmer and Räisänen (2002) analysed the modelled differences between the control run and an ensemble with transient increase in atmospheric concentration of carbon dioxide around the time it doubled (60-80 years from present). A considerable increase of the risk of a very wet winter in Europe (five-fold, and higher, increase over much of Europe) and a very wet monsoon season in Asian monsoon region was projected.

There have been a number of recent flood events world-wide, where all-time river flow or stage records were broken. The extensive flooding in July 1997 on the Odra and its tributaries in the Czech Republic, Poland, and Germany has been unprecented and historic records of flood stage and discharge were exceeded by a large margin. During the 2002 flood in Central and Eastern Europe, the record flow of the Vltava in Prague (Czech Republic) was observed. This was the only time in the 175 years of records when the flow rate exceeded $5000 \mathrm{~m}^{3} / \mathrm{s}$, while in 1941-2001 it never reached $2500 \mathrm{~m}^{3} / \mathrm{s}$. The maximum water level of the Elbe in Dresden (Germany), $940 \mathrm{~cm}$ observed on 17 August 2002, surpassed the former historical record by $63 \mathrm{~cm}$. Stages in excess of $800 \mathrm{~cm}$ were never observed in the period 1880-2001. However, historical data show that from 1785 to 1879 , such stages were observed five times during less than a century (four out of five times - in February or March), while between 1502 and 1783, the level of $800 \mathrm{~cm}$ was exceeded only once. The 2002 deluge resembled rare historical events from remote past. For example, on 21 July 1342, a St Magdalene's flood, caused by intensive rain, devastated large areas of Europe, causing thousands fatalities and immense destruction.

In view of recent dramatic floods, trends are sought in long time series of flood data. This activity is essential for planning flood protection systems, where system design has been traditionally based on the assumption of stationarity of river flow. If studies of climate change come to predict a significant increase in the severity of hydrological extremes in the warmer world, then the consequences for design codes of practice would be severe. One would have to design and build bigger storage volumes, at higher costs, to accommodate larger flood waves. Existing infrastructure, e.g. dikes, storm sewers, may not guarantee the adequate level of protection and may need to be re-developed.

A study of change detection in time series of annual maximum river flow, conducted by Kundzewicz et al. (2005), based on data from the Global Runoff Data Centre in Koblenz (Germany), does 
not support the hypothesis of ubiquitous growth of high flows worldwide. Although 27 cases of strong, statistically significant increase were identified by the Mann-Kendall test, there are 31 decreases as well, while most (137) records did not show statistically significant changes. There is an overwhelming natural variability in river flow. However, even if no coherent changes can be detected for European records, Kundzewicz et al. (2006) found that the overall 1961-2000 daily flow maxima occurred considerably more frequently (at 46 stations) in the later two decades, 1981-2000, than in the earlier two decades, 1961-1980 (maxima at 24 stations). Still, caution is advised in interpreting these results, because the analysis did not differentiate the flood generation mechanisms (e.g. snowmelt vs rainfall), treating all floods as one category. In a seasonal analysis, Mudelsee et al. (2003) demonstrated a significant decrease in winter floods on the Elbe and the Oder, while no significant change in summer floods was detected.

As stated by Radziejewski and Kundzewicz (2004), who examined detectability of artificially introduced (hence fully controlled) trends in time series, if a change is weak and lasts for a short time, it is not likely to be detected. If a change is stronger and lasts longer, the likelihood of detection grows. Hence, more time can be needed for detection of more significant trends.

A regional change in timing of floods has been observed in many areas, with increasing late autumn and winter floods. Furthermore, river flow has strong natural variability and exhibits long-term persistence which can confound the results of tests.
Milly et al. (2002) demonstrated that for 15 out of 16 large basins analysed worldwide, the control 100-year volumes of monthly river flow is projected to be exceeded more frequently as a result of carbon dioxide quadrupling. In some areas, such a flood is projected to be exceeded even every 2-5 years. Particularly strong increases in frequency of extremes are projected in northern Asia, although a large uncertainty in these projections is recognized. Impacts of extremes on human welfare are likely to occur disproportionately in countries with low adaptation capacity.

Floods have been identified in the IPCC TAR (IPCC, 2001) and IPCC AR4 (IPCC, 2007a) among regional reasons of concern. In the Himalaya, glacier melt will lead to increasing numbers and severity of melt-related floods (including glacial lake outburst floods), ice and rock avalanches from destabilized slopes (IPCC, 2007a). Flooded area in Bangladesh is projected to increase at least by 2 3-29\% with a global air temperature rise of $2^{\circ} \mathrm{C}$ (Mirza et al., 2003), i.e. warming that will very likely occur in the present century. Flash floods are likely to increase in all of Europe, while frequency and intensity of snowmelt-related floods in Central and Eastern Europe are expected to decline. In North America, projected warming in the western mountains is very likely to cause increased peak winter flows and flooding by the mid 21 st century.

Up to $20 \%$ of the world population live in river basins that are likely to be affected by increased flood hazard by 2080s in the course of global warming (Kleinen and Petschel-Held 2007).

Precipitation intensity increases almost everywhere, but particularly at mid- and 
high latitudes where mean precipitation also increases (Meehl et al. 2005). This directly affects the risk of flash flooding and urban flooding.

Based on the hydrological modelling for three case studies of urban flooding, Schreider et al. (2000) found increases in the magnitude and frequency of flood events under the double $\mathrm{CO}_{2}$ conditions. The 1 in 100-year flood under current conditions becomes the 1 in 44-year, the 1 in 35-year, and the 1 in 10-year event for three Australian case studies considered.

The average annual direct flood losses for these three case studies in Australia increase considerably (2-10 fold) for double $\mathrm{CO}_{2}$ conditions, as compared to present day. Hence, in general, storm drainage systems have to be adapted to accommodate increasing rainfall intensity resulting from climate change (Waters et al. 2003).

Semadeni-Davies et al. (2008) carried out a multi-factor study of projections of urban flood risk, including waste and stormwater flows. The climate change and continued urbanization are projected to exacerbate the current drainage problems in combined sewer system and flows to a suburban stream. Semadeni-Davies et al. (2008) found that city growth and projected increases in heavy rainfalls and therefore surface runoff, under changing climate, raise peak flow volumes and increaseflood risk. As shown by Semadeni-Davies et al. (2008), under assumption of urbanization and climate change, the combined sewer overflow volumes volumes could increase by $450 \%$ and the release of $\mathrm{NH}_{4}$ could have a 10 -fold increase. Adaptation is possible, though source control and increased storage capacity, and installation of a sustainable urban drainage system. The effects of climate change on dilution can be mitigated by stormwater disconnection and installation of water saving appliances in households.

In general, adaptation to increasing flood risk poses a difficult challenge to integrated flood preparedness and flood management systems, which should include an optimal, site-specific, mix of structural and non-structural measures.

In response to destructive floods in Europe since 1990, water managers in a few European countries, including the Netherlands, the UK, and Germany have begun to consider the implications of climate change explicitly in flood management and national flood protection design codes. In the UK, for example, design flood magnitudes are increased by $20 \%$ to reflect the possible effects of climate change, based on early impact assessments. Measures to cope with the increase of the design discharge for the Rhine in the Netherlands from 15000 to $16000 \mathrm{~m}^{3} / \mathrm{s}$ must be implemented by 2015 and it is planned to increase the design discharge to $18000 \mathrm{~m}^{3} / \mathrm{s}$ in the longer term due to climate change. In the German State of Bavaria, the design values have increased by $15 \%$.

On the European Union (27 countries) level, the Floods Directive (Directive... 2006) is adopted, embracing river floods, flash floods, urban floods, sewer floods and coastal floods. The Directive foresees that EU Member States shall first undertake a preliminary flood risk assessment, further - prepare flood maps and indicative flood damage maps, and finally - prepare and implement flood risk management plans. 


\section{CONCLUSIONS}

According to physical laws, the water-holding capacity of the atmosphere, and hence the potential for heavy rainfall, increases with warming. Since a robust warming signal and a number of large rain-fed floods have been observed recently in many regions, it is of paramount importance to seek trends in heavy precipitation and flood flows. However, even if widespread increases in observed heavy rainfall have been reported, the analysis of annual maximum river flow records does not detect a ubiquitous and coherent increasing trend. This is in disagreement with some projections for the future, which indicate potential for more heavy rainfall, augmenting flood risk.

Climate-related changes in flood frequency are complex and depend on the flood generating mechanism (e.g. heavy rainfall $v s$ spring snowmelt), affected in different ways by climate change. Increase in intense precipitation in the warming world is plausible and likely to lead to a rise of flood risk in areas where inundations are typically triggered by intense summer rain (Kundzewicz et al. 2005). Also, during wetter and warmer winters, with increasingly more frequent rain and less frequent snow in many areas, the flood risk may increase. On the other hand, snowmelt and ice-jam floods are likely to become less frequent and less severe over much of the warming world. Where snowmelt is earlier and less abundant, high flows come earlier in the year (sometimes in winter rather than spring) and the risk of spring floods decreases. The number of inundations caused by ice jams has gone down as a result of warming (more rivers do not freeze at all) and better human capacity to cope with ice-based obstructions of flow. Hence, in the regions where floods can be caused by several possible mechanisms, the net effect of climate change on flood risk is not trivial and a general and ubiquitously valid, flat-rate statement on change in flood risk cannot be made.

Methodological constraints to determine a design flood are manifold. Flood frequency analysis, addressing rare events and based on short (often non-homogeneous) records, involves high uncertainty, extrapolation (e.g. of the stage-discharge relation) and subjectivity (selection of a pdf) even in the stationary case. Since, as declared by Milly et al. (2008), stationarity is dead, the situation is much more complex: a discharge corresponding to an old 100-year flood may become a new 10 -year flood. Hence, the question arises - adapting to what?

There are a number of activities that could help in further improving understanding of the relationship between climate change and floods, in quantitative terms. Continuation of efforts of change detection and attribution, based on analysis of long time-series of quality-controlled observation records is indispensable. Also, continuation of efforts aimed at transforming the results of the latest generation of climate models into flood-related impacts is absolutely necessary. Since, as stated in IPCC (2001), the analysis of observations of extreme events is underdeveloped, there is a considerable merit in continuing change detection studies in order to identify a change sufficiently early and to react adequately.

\section{ACKNOWLEDGEMENTS}

The reported work has been a background activity within the integrated projects ENSEMBLES, ADAM, and WATCH 
of the Sixth Framework Programme of the European Union. Useful comments of an anonymous reviewer are gratefully acknowledged.

\section{REFERENCES}

DIRECTIVE of the European Parliament and of the Council on the assessment and management of floods, 2006: $\{\operatorname{SEC}(2006) 66\}$ (draft).

IPCC (Intergovernmental Panel on Climate Change), 2001: Climate Change 2001: Impacts, Adaptation and Vulnerability (edited by McCarthy J.J., Canziani O.F., Leary N.A., Dokken D.J. and White K.S.). Contribution of the Working Group II to the Third Assessment Report of the Intergovernmental Panel on Climate Change, Cambridge University Press, Cambridge, UK (available at http://www.ipcc.ch/ipccreports/ tar/wg2/index.htm site, last visited on 10 April 2008).

IPCC, 2007: Summary for Policymakers. In: Climate Change 2007: The Physical Science Basis. Contribution of Working Group I to the Fourth Assessment Report of the Intergovernmental Panel on Climate Change (eds Solomon S., Qin D., Manning M., Chen Z., Marquis M., Averyt K.B., Tignor M. and Miller H.L.). Cambridge University Press, Cambridge, UK and New York, NY, USA (available at http:// www.ipcc.ch/pdf/assessment-report/ar4/wg1/ ar4-wg1-spm.pdf site, last visited on 10 April 2008).

IPCC, 2007a: Climate Change 2007: Impacts, Adaptation and Vulnerability. Contribution of Working Group II to the Fourth Assessment Report of the Intergovernmental Panel on Climate Change (eds Parry M.L., Canziani O.F., Palutikof J.P., Hanson C.E. and van der Linden P.J.), Cambridge University Press, Cambridge, UK and New York, NY, USA (available at http://www.ipcc.ch/pdf/assessment-report/ar4/ wg2/ar4-wg2-chapter3.pdf site, last visited on 10 April 2008).

KLEINEN T., PETSCHEL-HELD G. 2007: Integrated assessment of changes in flooding probabilities due to climate change. Climatic Change, 81, 283-312.

KUNDZEWICZ Z.W., GRACZYK D., MAURER T., PIŃSKWAR I., RADZIEJEWSKI
M., SVENSSON C., SZWED M. 2005: Trend detection in river flow series: 1 . Annual maximum flow. Hydrol. Sci. J. 50(5), 797-810.

KUNDZEWICZ Z.W., MATA L.J., ARNELL N., DÖLL P., KABAT P., JIMÉNEZ B., MILLER K., OKI T., ŞEN Z., SHIKLOMANOV I. 2007: Freshwater resources and their management. Climate Change 2007: Impacts, Adaptation and Vulnerability. Contribution of Working Group II to the Fourth Assessment Report of the Intergovernmental Panel on Climate Change, (eds Parry M L., Canziani O.F., Palutikof J.P., Hanson C.E. and van der Linden P.J.), Cambridge University Press, Cambridge, UK and New York, NY, USA (available at http://www.ipcc.ch/pdf/assessment-report/ar4/ wg2/ar4-wg2-chapter3.pdf site, last visited on 22 March 2008).

KUNDZEWICZ Z.W., RADZIEJEWSKI M., PIŃSKWAR I. 2006: Precipitation extremes in the changing climate of Europe. Clim. Res. 31: 51-58.

KUNDZEWICZ Z.W., ROBSON A. J. 2004: Change detection in river flow records - review of methodology. Hydrol. Sci. J. 49(1): 7-19.

KUNDZEWICZ Z.W., SCHELLNHUBER H.-J. 2004: Floods in the IPCC TAR perspective. Natural Hazards 31: 111-128.

KUNDZEWICZ Z.W., TAKEUCHI K. 1999: Flood protection and management: Quo vadimus?, Hydrol. Sci. J., 44: 417-432.

MEEHL G.A., ARBLASTER J.M., TEBALDI C. 2005: Understanding future patterns of precipitation intensity in climate model simulations. Geophys. Res. Lett., 32, L18719, doi:10.1029/ 2005GL023680.

MILLY P.C.D., WETHERALD R.T., DUNNE K.A., DELWORTH T.L. 2002: Increasing risk of great floods in a changing climate. Nature 415, 514-517.

MILLY P.C.D., BETANCOURT J., FALKENMARK M., HIRSCH R.M., KUNDZEWICZ Z.W., LETTENMAIER D.P., STOUFFER R.J. 2008: Stationarity is Dead: Whither Water Management? Science, 319: 573-574, 1 February 2008.

MIRZA M.M.Q., WARRICK R.A., ERICKSEN N.J. 2003: The implications of climate change on floods of the Ganges, Brahmaputra and Meghna rivers in Bangladesh. Climatic Change, 57, 287-318. 
MUDELSEE M., BÖRNGEN M., TETZLAFF G., GRÜNEWALD U. 2003: No upward trends in the occurrence of extreme floods in central Europe. Nature 421, 166-169.

PALMER T.N., RÄISÄNEN J. 2002: Quantifying the risk of extreme seasonal precipitation events in a changing climate, Nature, 415, 512-514.

RADZIEJEWSKI M., KUNDZEWICZ Z.W. 2004: Detectability of changes in hydrological records. Hydrol. Sci. J. 49(1), 39-51.

SCHREIDER S.Y., SMITH D.I., JAKEMAN A.J. 2000: Climate change impacts on urban flooding. Climatic Change, 47, 91-115.

SEMADENI-DAVIES A., HERNEBRING C., SVENSSON G., GUSTAFSSON L.-G. 2008: The impacts of climate change and urbanization on drainage in Helsingborg, Sweden: Combined sewer system. J. Hydrol. 350, 100-113.

SEMADENI-DAVIES A., HERNEBRING C., SVENSSON G., GUSTAFSSON L.-G. 2008a: The impacts of climate change and urbanization on drainage in Helsingborg, Sweden: Suburban stormwater. J. Hydrol. 350, 114- 125.

VAN DER PLOG R.R., MACHULLA G., HERMSMEYER D., ILSEMANN J., GIESKA M., BACHMANN J. 2002: Changes in land use and the growing number of flash floods in Germany. In: Agricultural Effects on Ground and Surface Waters: Research at the Edge of Science and Society (ed. by J. Steenvoorden, F. Claessen and J. Willems), 317-322. IAHS Publ. 273. IAHS Press, Wallingford, UK.

WATERS D., WATT W.E., MARSALEK J., ANDERSON B.C. 2003: Adaptation of a storm drainage system to accommodate increased rainfall resulting from climate change. J. Environ. Plan. Manage., 46, 755-770.
Streszczenie: Ryzyko i wrażliwość na powodzie $w$ zmieniajacym sie klimacie. Powodzie są zjawiskiem naturalnym, które nęka ludzkość od początku historii. Jednak w ostatnich latach straty powodziowe są znacznie wyższe niż kiedyś, więc trzeba szukać interpretacji tego faktu. Powodzie rzeczne są złożonym procesem, na który wpływać mogą zmiany związane z systemami fizycznymi, klimatycznymi i społeczno-ekonomicznymi. Udział klimatu w obserwowanych zmianach jest prawdopodobny, nawet jeśli wkraczanie ludzi na tereny zagrożone powodzią i wzrost potencjału strat na obszarach zalewowych mogą być w wielu zlewniach rzecznych czynnikiem dominującym. Zaobserwowano wzrost silnych opadów, a w konsekwencji - rosnące ryzyko wezbrań deszczowych. Projekcje na przyszłość, oparte na regionalnych modelach klimatu, wskazuja na wzrost ryzyka i wrażliwości na powodzie $\mathrm{w}$ wielu regionach. Rozważono konsekwencje dla wezbrań na obszarach zurbanizowanych, w kontekście wielu czynników. Obecny artykuł przedstawia globalną perspektywę IPCC, w kontekście Czwartego Raportu IPCC oraz technicznego dokumentu dotyczącego zmian klimatu i wody, gdzie ZWK pełnił rolę koordynatora i autora prowadzącego.

\section{MS. received April 2008}

Author's address:

Zakład Badań Środowiska Rolniczego

i Leśnego PAN

Bukowska 19, 60-809 Poznań

e-mail: zkundze@man.poznan.pl

Poland 